\title{
Dynamics of dormancy regulation in 'Sonata' strawberry and its relation to flowering and runnering
}

\author{
Anita Sønsteby ${ }^{1 *}$ (10 and Ola M. Heide ${ }^{2}$
}

\begin{abstract}
Background: Dormancy regulation in strawberry is a dynamic process that is causally interrelated with regulation of flowering. Interference between the two processes is therefore possible.

Methods: We studied dormancy control and its relation to flowering and runner formation in 'Sonata' strawberry under daylight phytotron conditions. Growth and flowering were observed in plants pretreated for 5 or 10 weeks at 10-h SD and 18-h LD at 6 and $18{ }^{\circ} \mathrm{C}$ and subsequently forced in a greenhouse in LD at $20{ }^{\circ} \mathrm{C}$ with and without previous chilling for 6 weeks at $2{ }^{\circ} \mathrm{C}$ in darkness.

Results: SD induced constrained leaf and inflorescence growth at both 6 and $18{ }^{\circ} \mathrm{C}$, while the typical strawberry semi-dormant condition was attained only by exposure to SD at $18{ }^{\circ} \mathrm{C}$ for 10 weeks, which also completely blocked runner formation. The constrained leaf and inflorescence growth observed in plants grown in SD at $18{ }^{\circ} \mathrm{C}$ were partially reversed by 6 weeks of chilling and gradually overcome in successively emerging leaves. While plants grown in LD at $18{ }^{\circ} \mathrm{C}$ for 10 weeks remained vegetative under subsequent forcing, they unexpectedly initiated flowers when subjected to chilling in darkness for 6 weeks before the forcing.

Conclusions: SD exposure at $18{ }^{\circ} \mathrm{C}$ constrained leaf and inflorescence growth in 'Sonata' strawberry, and when applied for 10 weeks, it induced the persistent semi-dormant state that is typical for strawberry. Transient growth constraints were also induced at $6{ }^{\circ} \mathrm{C}$ in both SD and LD, while the semi-dormant state was only attained by SD at the higher temperature. Flowering in complete darkness, which is known in both SD and LD plants, did also take place in 'Sonata' strawberry in response to chilling in the dark at $2{ }^{\circ} \mathrm{C}$ for 6 weeks. While the potential impact of the phenomenon seems limited for regulation of flowering in strawberry, we conclude that chilling in the dark at near-freezing temperature may substantially enhance flowering in marginally induced strawberry plants.
\end{abstract}

Keywords: Constrained growth, Dormancy, Flowering, Fragaria x ananassa, Photoperiod, Runner formation, Temperature

\section{Introduction}

The June-bearing or seasonal flowering (SF) strawberry cultivars are classified as facultative short day (SD) plants (Darrow and Waldo 1934; Guttridge 1985; Heide et al. 2013). At temperatures $>18-20{ }^{\circ} \mathrm{C}$, they need SD

\footnotetext{
*Correspondence: anita.sonsteby@nibio.no

${ }^{1} \mathrm{NIBIO}$, Norwegian Institute of Bioeconomy Research, 1431 Ås, Norway

Full list of author information is available at the end of the article
}

for induction of flowering, while at lower temperatures, most cultivars also initiate flowers under long day (LD) conditions (Ito and Saito 1962; Heide 1977; Guttridge 1985; Heide et al. 2013). Therefore, under natural environmental conditions, flower bud formation takes place in response to the decreasing daylength and temperature conditions of autumn.

Under prolonged SD conditions, SF strawberry plants will gradually enter a state of dormancy (Darrow and

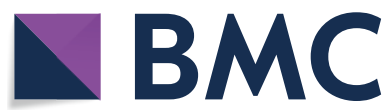

(c) The Author(s) 2021. This article is licensed under a Creative Commons Attribution 4.0 International License, which permits use, sharing, adaptation, distribution and reproduction in any medium or format, as long as you give appropriate credit to the original author(s) and the source, provide a link to the Creative Commons licence, and indicate if changes were made. The images or other third party material in this article are included in the article's Creative Commons licence, unless indicated otherwise in a credit line to the material. If material is not included in the article's Creative Commons licence and your intended use is not permitted by statutory regulation or exceeds the permitted use, you will need to obtain permission directly from the copyright holder. To view a copy of this licence, visit http://creativeco mmons.org/licenses/by/4.0/. The Creative Commons Public Domain Dedication waiver (http://creativecommons.org/publicdomain/ zero/1.0/) applies to the data made available in this article, unless otherwise stated in a credit line to the data. 
Waldo 1934; Guttridge 1985; Heide et al. 2013). However, the dormant state in strawberry is not absolute, but rather a state of semi-dormancy since plants grown under natural autumn conditions continue to produce new leaves and are able to re-initiate growth when transferred to LD and elevated temperature, even in November when the deepest state of dormancy is attained (Jonkers 1965; Guttridge 1985; Sønsteby and Heide 2006). The semi-dormant state is characterized by strong restriction of vegetative growth. Emerging leaves are small with short petioles, flower peduncles are dwarfed, no runners are formed, and the plants attain a stunted habit (Jonkers 1965; Guttridge 1985). Sønsteby and Heide (2006) found that while growth was strongly restricted by 5 weeks of SD exposure at intermediate temperatures, 10 or more weeks of SD were required for induction of a persistent semi-dormant state in the cultivars 'Elsanta' and 'Korona'. Furthermore, the dormant state was only attained by SD exposure at relatively warm temperature conditions $\left(15{ }^{\circ} \mathrm{C}\right)$, while at $6{ }^{\circ} \mathrm{C}$, the dormant state was not attainable even with extended SD exposure for 15 weeks (cf. Kronenberg et al. 1976). Release from dormancy and full reversal of the restrained growth habit require several weeks of chilling at -2 to $6{ }^{\circ} \mathrm{C}$, while $10{ }^{\circ} \mathrm{C}$ is only marginally effective (Guttridge 1985; Lieten 1997; Heide et al. 2013). Prolonged exposure to LD conditions will also gradually break dormancy and bring about normal growth even in fully dormant plants (Lieten 1997; Sønsteby and Heide 2006). Since temperatures up to 10 ${ }^{\circ} \mathrm{C}$ are effective in breaking dormancy in strawberry, continuous exposure to SD at such low temperatures seems to continuously nullify the dormancy-inducing effect of SD (Sønsteby and Heide 2006).

This brief literature overview shows that regulation of dormancy in strawberry is a dynamic process that is mainly controlled by photoperiod and temperature. The same environmental conditions are also controlling physiologically and economically important processes such as flowering and runner formation (sexual and vegetative reproduction) in strawberry. We have therefore studied the relationship between these processes in the widely grown SF cultivar 'Sonata' with a view to better understand to what extent environmental manipulations for dormancy regulation might interfere with flowering in out-of-season strawberry production.

\section{Materials and methods}

Non-rooted runner plants were collected in the field at the NIBIO Experimental Centre Apelsvoll in South East Norway $\left(60^{\circ} 40^{\prime} \mathrm{N}, 10^{\circ} 40^{\prime} \mathrm{E}\right)$ on 27 July and rooted in a heated greenhouse at water-saturated atmosphere under a cover of opaque plastic. The runners were rooted directly in $10 \mathrm{~cm}$ plastic pots in a peat-based potting compost (Gartnerjord, LOG, Oslo) mixed with $10 \%(\mathrm{v} / \mathrm{v})$ granulated perlite. From rooting and throughout the experiment, the plants were watered as needed, alternating between tap water and a slightly modified Hoagland nutrient solution with electric conductivity of $1.3 \mathrm{mS} \mathrm{cm}^{-1}$. During rooting and early growth, the plants were maintained at a minimum temperature of $20^{\circ} \mathrm{C}$ and 20-h photoperiod provided by extension of the natural daylength with low-intensity light from incandescent lamps.

Then on 17 August, the plants were transferred to the daylight phytotron at the Norwegian University of Life Sciences at Ås, Norway $\left(59^{\circ} 40^{\prime} \mathrm{N}, 10^{\circ} 45^{\prime} \mathrm{E}\right)$ and exposed to 10-h SD and 18-h LD at temperatures of 6 and 18 ${ }^{\circ} \mathrm{C}$ for 5 and 10 weeks. At this stage, the plants had 3-4 leaves. In the phytotron, the plants were exposed to natural daylight conditions for $10 \mathrm{~h}(0800-1800 \mathrm{~h})$, and then moved into adjacent growth rooms from $1800-0800 \mathrm{~h}$ where they were either in darkness for $14 \mathrm{~h}$ or exposed to low-intensity light $\left(\sim 7 \mu \mathrm{mol}\right.$ quanta $\left.\mathrm{m}^{-2} \mathrm{~s}^{-1}\right)$ from $70 \mathrm{~W}$ incandescent lamps for daylength extension to $18 \mathrm{~h}$ (1800-0400 h). Whenever the photosynthetic photon flux (PPF) dropped below $150 \mu \mathrm{mol}$ quanta $\mathrm{m}^{-2} \mathrm{~s}^{-1}$ during daytime, an additional $125 \mu \mathrm{mol}$ quanta was automatically added using $400 \mathrm{~W}$ Philips HPT-I lamps. Temperatures were controlled to $\pm 1.0^{\circ} \mathrm{C}$, and a water vapour pressure deficit of $530 \mathrm{~Pa}$ was maintained at all temperatures.

After completion of the 5- and 10-week treatment periods in the phytotron, one half of the plants in each treatment were moved back to Apelsvoll and forced in a greenhouse at $18-20{ }^{\circ} \mathrm{C}$ and 20 -h photoperiod for recording of growth and flowering performance, while the other half was chilled at $2{ }^{\circ} \mathrm{C}$ in the dark for 6 weeks before forcing. During the chilling period, darkness was regularly interrupted for 10-15 min. at weekly intervals for inspection of water status and watering as needed. During forcing, the plants received the current natural daylight plus $150 \mu \mathrm{mol} \mathrm{m} \mathrm{m}^{-2} \mathrm{~s}^{-1}$ supplemental light from $400 \mathrm{~W}$ Philips HPT-I lamps for $20 \mathrm{~h}(0200-2200 \mathrm{~h})$.

\section{Experimental design, data collection and analyses}

The experiment had a split plot design with temperatures as main plots and photoperiod, and duration of treatments and chilling as subplots. Each treatment had six replications, each with four plants. However, three of the replications were terminated and dissected for assessment of the floral development status of the main crown after completion of the 5- and 10- week phytotron treatment periods. Floral development was scored according to the six-stage scale used by Opstad et al. (2011).

At the termination of the phytotron treatments (after 5 and 10 weeks), and at weekly intervals during forcing, 
the number of emerged leaves, runners and inflorescences, as well as the date of first anthesis were recorded in each plant. In addition, the petiole length of each of the first three emerging leaves, and the length of emerging inflorescences (peduncle + pedicel) and the date of first anthesis were recorded at weekly intervals during forcing. Finally, after 10 weeks of forcing, the total number of flowers in each inflorescence and leaf area of the three first emerging and the last developed leaves were also recorded. The area of the mid and left leaflet of each leaf was measured with a LI-COR Inc. Model LI-3000 area meter as described by Sønsteby et al. (2016). All presented leaf areas refer to these measurements.

Experimental data were subjected to analysis of variance (ANOVA) by standard procedures, while Tukey's multiple comparison test was used to assess the significance of differences between means. All analyses were performed with a MiniTab ${ }^{\circledR}$ Statistical Software program package (Release 17.1.0. Minitab. Inc., State College, PA, USA). Percentage values were always subjected to an arc sin transformation before performance of the ANOVA.

\section{Results}

Temperature and daylength induced constraints of growth and flowering

The vegetative and generative development states of plants at termination of the 5- and 10- week treatment periods at the various temperature and daylength conditions are shown in Table 1. The formation of new leaves was not affected by photoperiod at any of the temperatures (no temperature $\times$ photoperiod interaction), but was significantly enhanced by elevated temperature, especially with the longer treatment duration. On the other hand, while elevated temperature and LD enhanced leaf area growth, prolonged SD exposure strongly restricted leaf area expansion at both temperatures. It should be noticed, however, that at $6{ }^{\circ} \mathrm{C}$, leaf expansion was constrained by prolonged exposure also under LD conditions, but due to the highly significant main effects of all factors, this three-factor interaction was not significant.

Floral initiation took place in both SD and LD at 6 ${ }^{\circ} \mathrm{C}$, while at $18{ }^{\circ} \mathrm{C}$ in SD only (Table 1 ). However, due to

Table 1 Vegetative and generative development states of 'Sonata' plants after exposure to different temperatures and photoperiods for 5 and 10 weeks as indicated

\begin{tabular}{|c|c|c|c|c|c|c|c|}
\hline Temperature $\left({ }^{\circ} \mathrm{C}\right)$ & $\begin{array}{l}\text { Photoperiod } \\
\text { (h) }\end{array}$ & $\begin{array}{l}\text { Duration } \\
\text { of treatment } \\
\text { (weeks) }\end{array}$ & $\begin{array}{l}\text { No. } \\
\text { of leaves } \\
\text { plant }^{-1}\end{array}$ & Leaf area $\left(\mathrm{mm}^{2}\right)^{a}$ & $\begin{array}{l}\text { Plants with visible } \\
\text { floral primordia } \\
(\%)\end{array}$ & $\begin{array}{l}\text { Floral } \\
\text { development } \\
\text { (stage 1-6) }\end{array}$ & $\begin{array}{l}\text { No. } \\
\text { of runners } \\
\text { plant }^{-1}\end{array}$ \\
\hline \multirow[t]{6}{*}{6} & 10 & 5 & $5.1 c^{b}$ & $22.0 d$ & $0.0 b$ & $1.4 \mathrm{C}$ & 1.4de \\
\hline & & 10 & $5.6 c$ & $14.5 \mathrm{ef}$ & $91.7 a$ & $3.8 b$ & $1.5 \mathrm{de}$ \\
\hline & & Mean & 5.3 & 18.2 & 45.8 & 2.6 & 1.5 \\
\hline & 18 & 5 & $5.3 c$ & $21.5 \mathrm{de}$ & $8.3 b$ & $1.5 c$ & $1.8 \mathrm{cde}$ \\
\hline & & 10 & $5.6 c$ & $13.0 f$ & $100.0 \mathrm{a}$ & $4.2 b$ & $1.1 \mathrm{e}$ \\
\hline & & Mean & 5.5 & 17.2 & 54.2 & 2.8 & 1.4 \\
\hline \multirow[t]{6}{*}{18} & 10 & 5 & $7.7 \mathrm{~b}$ & $39.6 c$ & $100.0 \mathrm{a}$ & $5.4 a$ & $2.8 \mathrm{C}$ \\
\hline & & 10 & $12.7 a$ & $19.1 \mathrm{def}$ & $100.0 \mathrm{a}$ & $5.9 a$ & $2.6 c d$ \\
\hline & & Mean & 10.2 & 29.3 & 100.0 & 5.7 & 2.7 \\
\hline & 18 & 5 & $7.9 b$ & $71.2 \mathrm{a}$ & $0.0 b$ & $1.0 \mathrm{C}$ & $4.6 b$ \\
\hline & & 10 & $11.3 a$ & $59.0 b$ & $0.0 \mathrm{~b}$ & $1.0 \mathrm{c}$ & $8.2 \mathrm{a}$ \\
\hline & & Mean & 9.6 & 65.1 & 0.0 & 1.0 & 6.4 \\
\hline \multicolumn{8}{|c|}{ Probability level of significance (ANOVA) } \\
\hline \multicolumn{8}{|c|}{ Source of variation } \\
\hline Temperature (A) & & & $<0.001$ & 0.007 & n.s & n.s & 0.002 \\
\hline Photoperiod (B) & & & n.s & 0.001 & $<0.001$ & $<0.001$ & $<0.001$ \\
\hline$A \times B$ & & & n.s & 0.001 & $<0.001$ & $<0.001$ & $<0.001$ \\
\hline Duration of treatment $(C)$ & & & $<0.001$ & $<0.001$ & $<0.001$ & $<0.001$ & 0.001 \\
\hline$C \times A$ & & & $<0.001$ & 0.008 & $<0.001$ & $<0.001$ & $<0.001$ \\
\hline$C \times B$ & & & 0.005 & n.s & n.s & n.s & 0.001 \\
\hline$A \times B \times C$ & & & 0.01 & n.s & n.s & n.s & $<0.001$ \\
\hline
\end{tabular}

The data are means of three replications with four plants each

n.s. not significant

${ }^{\text {a }}$ Leaf area of the last fully developed leaf

b Mean values within the same column followed by different lower-case letters indicate a significant difference $(P<0.05)$ between treatments 
this highly significant $(P<0.001)$ temperature $\times$ photoperiod interaction, the main effect of temperature did not become significant. At both photoperiods at $6{ }^{\circ} \mathrm{C}$, and in $\mathrm{SD}$ at $18{ }^{\circ} \mathrm{C}$, floral development progressed steadily over time, but anthesis was not reached in any treatment before they were terminated after 10 weeks. Runner formation was stimulated by LD and high temperature, and only in LD at $18{ }^{\circ} \mathrm{C}$ did runner formation continue during the second 5- week treatment period. Under all other treatment conditions, runner formation had ceased during the first 5 weeks of treatment and did not recover under continued treatment. Cessation of runner formation was advanced and promoted by low temperature and $\mathrm{SD}$, and although still at a relatively low level, runner formation increased significantly when the treatments were extended from 5 to 10 weeks. The main effects of all three factors as well as their two- and three-factor interactions were all highly significant (Table 1).

\section{Chilling release of growth and flowering constraints}

The constrained vegetative growth induced by $18{ }^{\circ} \mathrm{C}$ and SD for 5 weeks was transient and gradually reversed in successive leaves during subsequent forcing under growth-non-limiting conditions (Table 2). However, when the pretreatment was prolonged to 10 weeks, the growth constraint was more severe and persistent and only partially reversible by chilling in the dark at $2{ }^{\circ} \mathrm{C}$ for 6 weeks. In the less constrained plants grown at $6{ }^{\circ} \mathrm{C}$, the reversal was greater and faster, as was also the reversal effect of chilling.

The dynamics of the reversal of petiole growth ability of successively emerging leaves are presented in Fig. 1. The results show that persistence of the constrained petiole elongation decreased progressively in successively emerging leaves. Thus, leaf \#1, which developed during the pretreatments, was more or less fixed in the growth constrained mode, and therefore, much less responsive to the growth-promoting effect of chilling than were later emerging leaves. Whereas petiole elongation in leaves grown at $6{ }^{\circ} \mathrm{C}$ always was unaffected by photoperiod, petiole elongation was strongly constrained only under SD conditions at $18{ }^{\circ} \mathrm{C}$. The reversal of petiole elongation ability was also easier and more rapid in leaves grown at 6 ${ }^{\circ} \mathrm{C}$ in which normal petiole elongation was re-established during the first 5 weeks of the forcing period, in lateemerging leaves even without chilling. This was not the case in leaves developed at $18{ }^{\circ} \mathrm{C}$. Furthermore, in lateemerging leaves at $6{ }^{\circ} \mathrm{C}$, an excessive petiole growth was induced by the chilling treatment. The later the leaves were initiated, the less were the growth restriction and its persistence.

An unexpected and surprising result was that 6 weeks of chilling in the dark at $2{ }^{\circ} \mathrm{C}$ had the same effect on petiole elongation as plant growth in $\mathrm{SD}$ at $18{ }^{\circ} \mathrm{C}$ for 5 weeks. As seen from Fig. 1, the petiole length of leaf \#1 after 5 weeks of growth under LD conditions at 18 ${ }^{\circ} \mathrm{C}$ was twice the length of that of the corresponding leaf in SD. However, after 6 weeks of chilling at $2{ }^{\circ} \mathrm{C}$ in the dark, petiole growth was reduced to the same low level in plants from both daylengths. In other words, chilling for 6 weeks in the dark at $6{ }^{\circ} \mathrm{C}$, imitated the effects of 5 weeks SD exposure at $18{ }^{\circ} \mathrm{C}$. The response was analogous in leaves \#2 and \#3, and the same tendency was also observed with 10 weeks of pretreatment at the same conditions. As discussed later, chilling treatment in the dark also induced flowering in plants previously grown at 18 ${ }^{\circ} \mathrm{C}$ in LD.

Similar dynamics of reversal were demonstrated for runner formation (Table 2). With 5 weeks of pretreatment, runner formation was gradually re-initiated during forcing in plants from all pretreatment conditions, even without chilling (cf. Table 1). In plants pretreated in LD at $18{ }^{\circ} \mathrm{C}$, which had not ceased forming runners during the pretreatment, runnering progressed uninterruptedly after transfer to forcing conditions. However, when the pretreatments were extended to 10 weeks, runner formation was permanently suppressed in plants pretreated in $\mathrm{SD}$ at $18{ }^{\circ} \mathrm{C}$, and with only slight reversal by chilling for 6 weeks. With prolonged pretreatment for 10 weeks, reinitiation of runner formation was significantly repressed also in plants grown at $6{ }^{\circ} \mathrm{C}$ under both daylength conditions, and again with only slight reversal by chilling.

Much the same dynamics of responses were demonstrated for leaf area growth during forcing. (Table 2). Regardless of pretreatment conditions, the subsequent leaf area growth increased steadily in successively developing leaves, while the amount of area growth varied strongly in response to the different temperature and photoperiod pretreatment conditions. In plants grown at $6{ }^{\circ} \mathrm{C}$ for 5 weeks, subsequent leaf area growth was unaffected by photoperiod during the pretreatment, whereas SD conditions strongly constrained area growth in the plants grown at $18{ }^{\circ} \mathrm{C}$. This SD response was particularly pronounced with 10 weeks pretreatment, which also enhanced the persistence of growth suppression across successive leaves and rendered the plants less responsive to chilling. In the final leaf developed during the forcing period, however, the constrained area growth was usually completely overcome in plants from all pretreatment conditions (Table 2), a prominent exception being the non-chilled plants grown in $\mathrm{SD}$ at $18{ }^{\circ} \mathrm{C}$ for 10 weeks. However, pronounced two- and three-factor interactions often concealed the main effects of the various treatment factors.

The parallel effects on flowering and flower development are presented in Table 3. It is seen that exposure to 


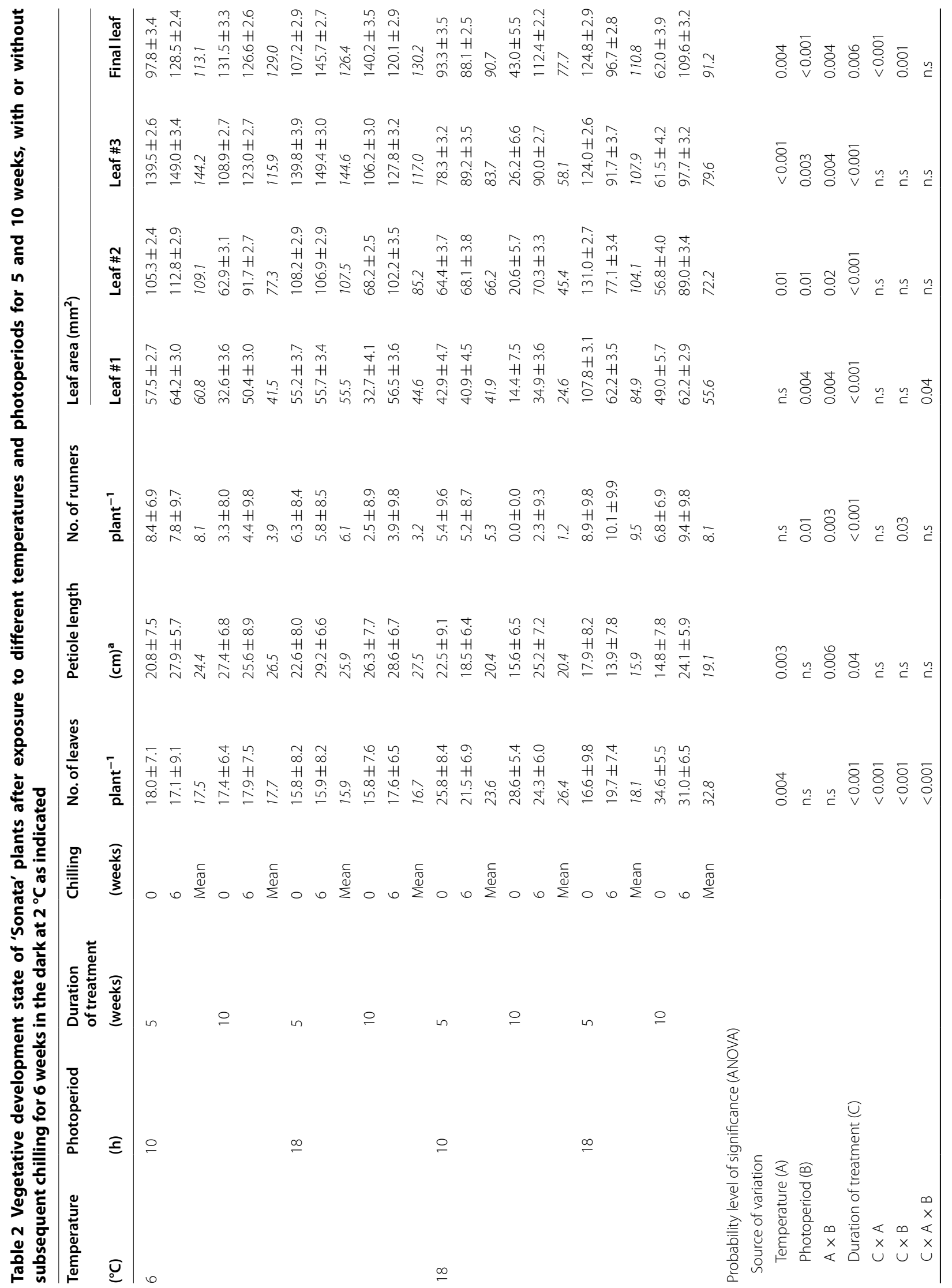




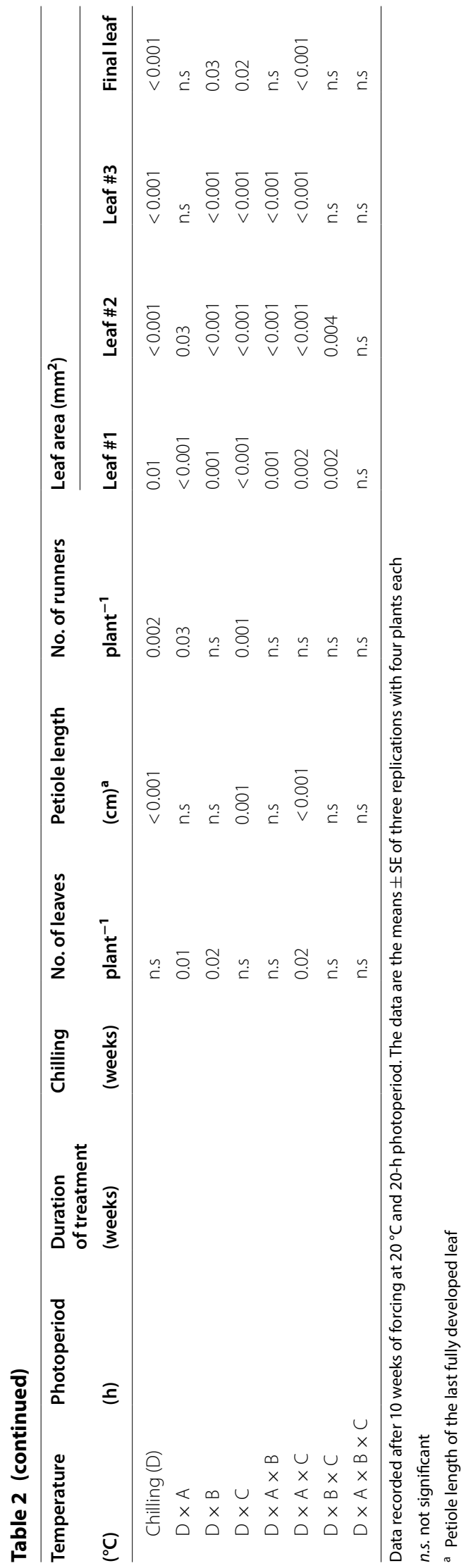



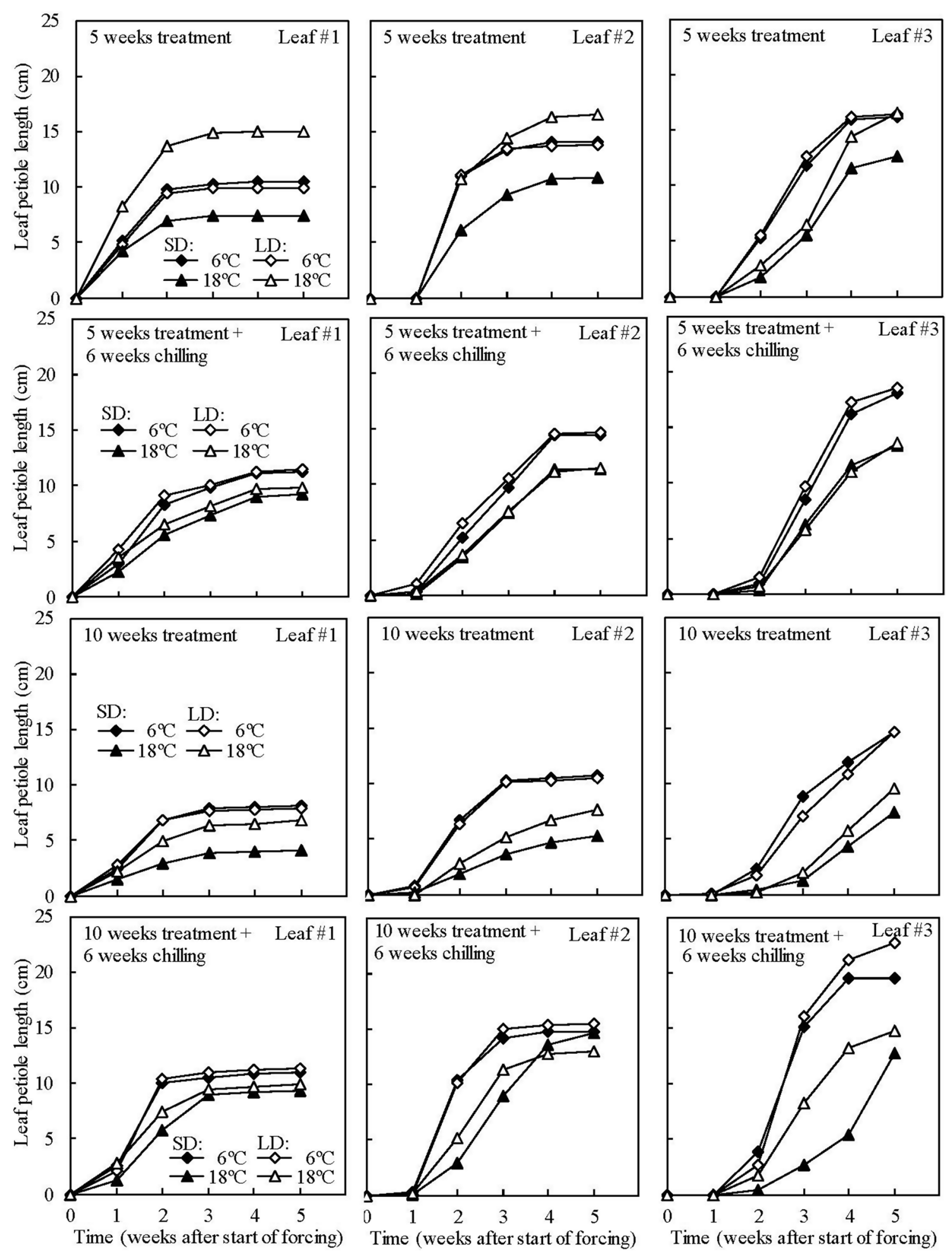

Fig. 1 Time courses of petiole elongation during the first 5 weeks of forcing in successive leaves of 'Sonata' strawberry plants exposed to temperature and photoperiod pretreatments as shown for 5 weeks and 10 weeks with or without subsequent chilling in the dark at $2^{\circ} \mathrm{C}$. The data are the means of three replications with four plants each 


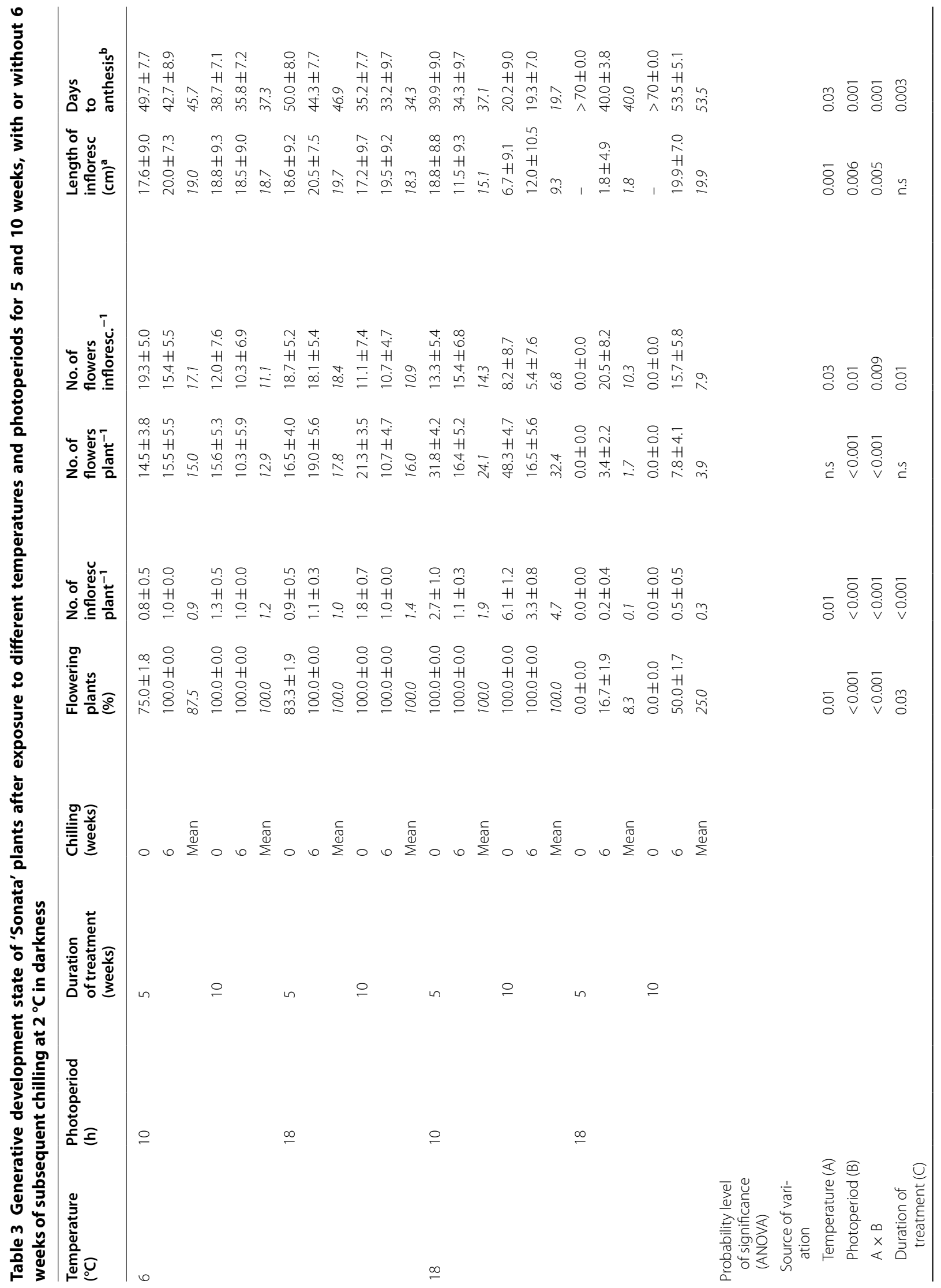




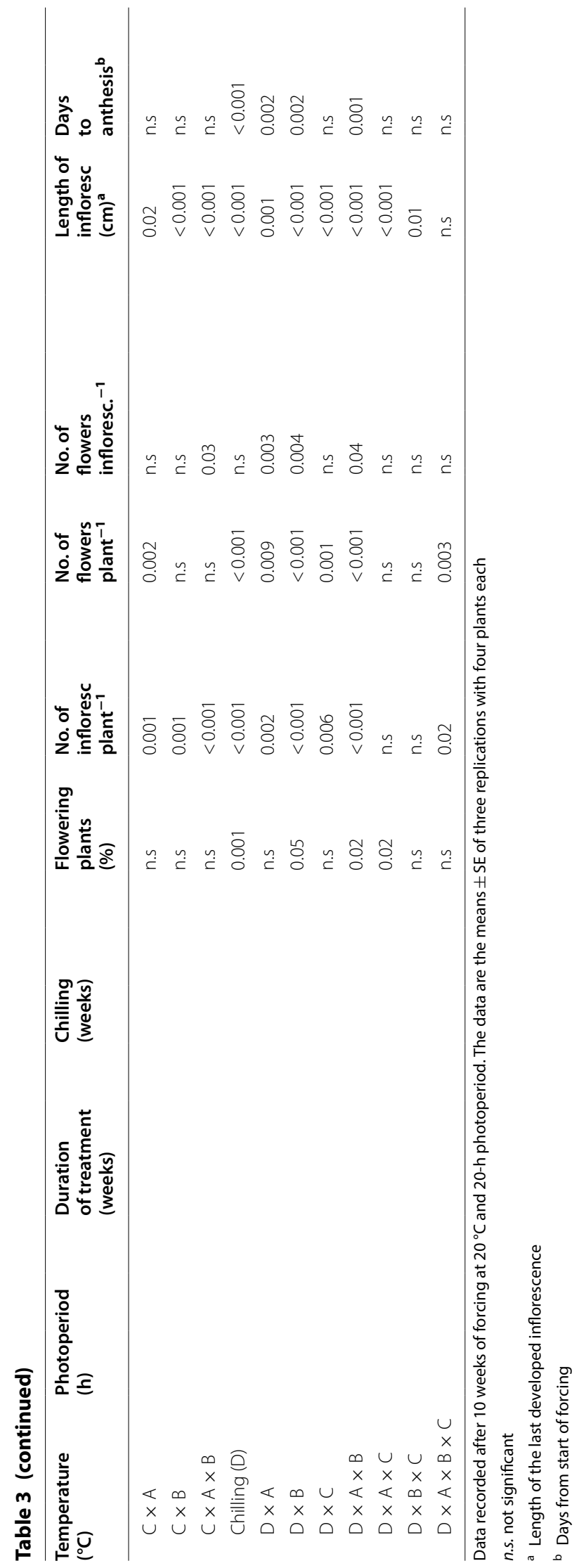


$6{ }^{\circ} \mathrm{C}$ for 5 or 10 weeks resulted in flowering in both SD and LD conditions, whereas at $18{ }^{\circ} \mathrm{C}$ in SD only (significant main effects and interactions of temperature and photoperiod). Similar effects were also found on number of inflorescences and flowers per plant, whereas number of flowers per inflorescence tended to decrease in plants with many inflorescences. A surprising effect was that the dark chilling treatment could induce flowering in plants previously grown under non-inductive LD conditions at $18{ }^{\circ} \mathrm{C}$ : thus, in plants grown in 18 -h LD at 18 ${ }^{\circ} \mathrm{C}$ for 10 weeks, subsequent chilling in the dark at $2{ }^{\circ} \mathrm{C}$ for 6 weeks induced flowering in $50 \%$ of the plants (one inflorescence per plant). A single plant did also flower in plants grown under the same non-inductive conditions for 5 weeks, but elongation of the inflorescence was severely suppressed. In addition, the partially flowering plants grown in SD or LD for 5 weeks at $6{ }^{\circ} \mathrm{C}$, were all flowering when subsequently chilled in darkness for 6 weeks.

After 10 weeks of forcing at $20{ }^{\circ} \mathrm{C}$ and 20-h LD conditions, all plants pretreated at $6{ }^{\circ} \mathrm{C}$ for 5 or 10 weeks developed inflorescences with adequate, $18-20 \mathrm{~cm}$ height, and subsequent chilling did not substantially change this result (Table 3). However, in plants grown in SD at $18{ }^{\circ} \mathrm{C}$ for 10 weeks, inflorescence elongation was severely constrained to $\sim 7 \mathrm{~cm}$ height, and subsequent chilling could only partially reverse the constraint. On the other hand, plants grown at the same conditions for only 5 weeks, developed almost normal inflorescence heights, whereas chilling of these plants surprisingly reduced inflorescence height to about $12 \mathrm{~cm}$. This was apparently another aspect of the SD-like effect of the dark/chilling treatment. All plants induced to flower by chilling developed inflorescences with normal heights (Table 3 ).

Time to first anthesis was not affected by photoperiod in plants grown at $6{ }^{\circ} \mathrm{C}$ for 5 weeks but was reduced by nearly a week by the chilling treatment and by $10-15$ days when the exposure time was increased to 10 weeks (Table 3). However, in plants induced to flower in SD at $18{ }^{\circ} \mathrm{C}$, anthesis was advanced by $\sim 15$ days compared with induction at $6{ }^{\circ} \mathrm{C}$, while the advancement effect of chilling was markedly reduced. In plants induced to flower by chilling in the dark, anthesis was late indicating that floral initiation had taken place during the chilling treatment.

\section{Discussion}

The results confirm that SD induction of the growth-constrained semi-dormant state of SF strawberry plants is only displayed at relatively warm temperature conditions. This has been demonstrated in a range of SF cultivars (Kronenberg et al. 1976; Sønsteby and Heide 2006) as well as in the wild-growing wood strawberry (Sønsteby and Heide 2011) and seems to be a general characteristic of the strawberry genus at large. Since temperatures $<10{ }^{\circ} \mathrm{C}$ are effective in breaking dormancy in strawberry (Jonkers 1965; Guttridge 1985; Lieten 1997), it seems that such low growth temperatures $\left(0-10{ }^{\circ} \mathrm{C}\right)$ might continuously nullify the dormancy-inducing effect of SD and therefore fail to induce dormancy (cf. Sønsteby and Heide 2006). The results further confirm that 5 or more weeks of exposure to $\mathrm{SD}$ and intermediate temperature are required for establishment of the persistent semi-dormant condition, and Sønsteby and Heide (2006) found that the effect was further strengthened when the exposure was extended to 15 weeks.

In agreement with the common behavior of SF strawberries (Guttridge 1985; Heide et al. 2013), runner formation was promoted by LD and high temperature (Tables 1, 2). In plants pretreated in SD at $18{ }^{\circ} \mathrm{C}$ for 10 weeks, runner formation was completely blocked, and the inhibition was only slightly reversed by chilling. Overall, runner formation was the process that was most severely and persistently constrained by SD.

As previously found for the cultivars 'Elsanta' and 'Korona' (Sønsteby and Heide 2006), the formation of new leaves was enhanced by elevated temperature but unaffected by photoperiod and thus continued at constant rate in SD. On the other hand, leaf area and petiole as well as inflorescence elongation, were all markedly constrained by SD at $18{ }^{\circ} \mathrm{C}$. Leaves and inflorescences initiated during 10 weeks of dormancy-inducing treatments were more or less fixed in the semi-dormant constrained habit and only slightly influenced by chilling, while their growth constraints were progressively earlier reversed in successively later formed organs, even without chilling (Tables 2, 3). In commercial production, constrained inflorescence elongation is of greatest economic interest (Jonkers 1965; Lieten 1997) as it is associated with reduced berry size and more laborious harvesting. Under the present experimental conditions, more than 6 weeks of chilling at $2{ }^{\circ} \mathrm{C}$ were required to ensure adequate length of the first developing fruit trusses if the plants had previously been exposed to $\mathrm{SD}$ floral induction at $18{ }^{\circ} \mathrm{C}$ for 10 weeks (Table 3; Fig. 2). This is in good agreement with the results reported by Lieten (2009) for this cultivar.

Generally, the flowering results presented in Table 3, are in full agreement with the commonly found flowering responses of SF strawberries (Heide et al. 2013). However, a remarkable and most interesting finding was that chilling at $2{ }^{\circ} \mathrm{C}$ in the dark could replace or imitate the flower-inducing and growth-inhibiting effect of $\mathrm{SD}$ at intermediate temperature (Table 3; Fig. 1). While exposure to 18 -h $\mathrm{LD}$ at $18{ }^{\circ} \mathrm{C}$ did not induce flowering even after 10 weeks of exposure, $50 \%$ of the plants flowered after subsequent chilling at $2{ }^{\circ} \mathrm{C}$. Such a treatment also enhanced the flower-inducing effect of 5 weeks 


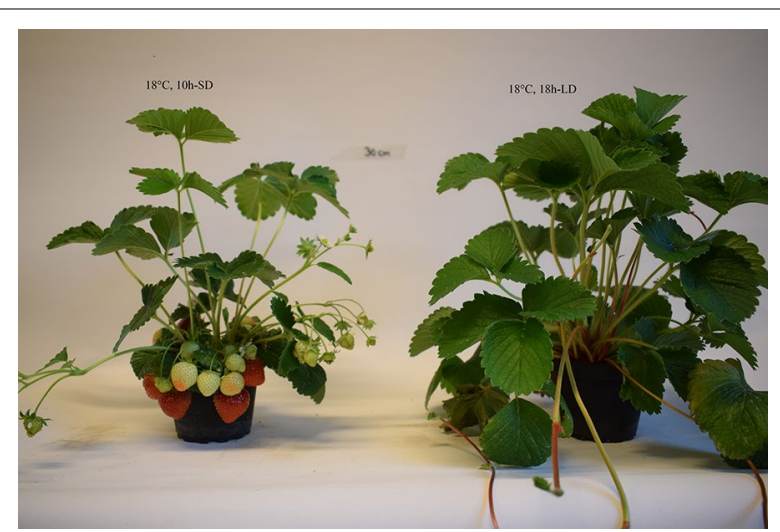

Fig. 2 Appearance of 'Sonata' strawberry plants after 10 weeks of forcing at $20^{\circ} \mathrm{C}$ and 20 -h photoperiod after different pretreatments as indicated. Note the stunted growth of early formed inflorescences in plants exposed to 10 weeks of SD pretreatment at $18{ }^{\circ} \mathrm{C}$, and the runner formation in plants exposed to $L D$ at the same temperature

exposure to $\mathrm{SD}$ at $6{ }^{\circ} \mathrm{C}$. Furthermore, $18{ }^{\circ} \mathrm{C} / \mathrm{LD}$ stimulation of petiole elongation in the first developing leaves were completely reversed after 6 weeks of chilling to the same constrained level as in plants grown in SD (Fig. 1). These puzzling results demonstrate that under certain conditions, the combination of darkness and near-freezing temperature can have the same effect as SD exposure at intermediate temperature. The fact that plants pretreated at $18 \mathrm{~h}$ photoperiod for 5 weeks, did not flower in response to chilling whereas plants pretreated for 10 weeks did flower, indicates that the pretreatment somehow enhanced the plants' sensitivity to flower induction. This suggests that a photoperiod of $18 \mathrm{~h}$, which in itself was non-inductive for flowering but is near the critical photoperiod for many cultivars (Heide 1977), has facilitated flower formation in the chilled plants by rendering them highly sensitive to floral induction and possibly induced a fractional floral induction in LD at 18 ${ }^{\circ} \mathrm{C}$ before the chilling was started. Likewise, the dissection results in Table 1 also showed that no visible floral primordia had been initiated during the pretreatments.

While flower induction in darkness is previously unknown in strawberry, the flowering physiology literature contains many examples of flower induction in complete darkness in both SD and LD plants as well as in cold (vernalization) requiring plants if an adequate carbohydrate (energy) status of the plant is maintained (Lang 1965). For example, aseptically cultivated plants of the model SD plant Pharbitis nil cultivated on a 5\% sucrose medium at $20{ }^{\circ} \mathrm{C}$ initiated flower buds in continuous darkness as well as in short photoperiods but not in continuous light (Takimoto 1960). Sugar beetroots, which require a sequence of chilling (vernalization) and
LD to flower, are also able to flower in complete darkness after vernalization (Lang 1965). Since crowns and leaves of dormant 'Sonata' plants are relatively rich in starch and sugars (Sønsteby et al. 2016), and since energy consumption is low at $2{ }^{\circ} \mathrm{C}$, it is not really surprising that the plants were able to initiate flower buds in darkness at near-freezing temperature. It may be, however, that such flower formation only may take place if previously prompted by marginal induction.

\section{Conclusion}

Short day exposure at intermediate temperature $\left(18{ }^{\circ} \mathrm{C}\right)$ strongly constrained leaf and inflorescence growth and suppressed runner formation in the SF strawberry cultivar 'Sonata'. When applied for 10 weeks, such conditions also induced the persistent semi-dormant state that is typical for strawberry. Similar growth constraints were also induced at $6{ }^{\circ} \mathrm{C}$ by both $\mathrm{SD}$ and LD, but under these conditions the constraints were transient and easily reversible.

While plants grown in $18-\mathrm{h} \mathrm{LD}$ at $18{ }^{\circ} \mathrm{C}$ did not flower under subsequent $\mathrm{LD}$ forcing at $20{ }^{\circ} \mathrm{C}, 50 \%$ of the plants exposed to such treatment flowered when a period of chilling in darkness at $2{ }^{\circ} \mathrm{C}$ was intercalated before forcing. While flower induction at near-freezing temperature in darkness is previously unknown in strawberry, many examples of flower induction in complete darkness is known in both SD and LD plants as well as in vernalization requiring plants, and we conclude that strawberry can now be added to the list of such plants.

\section{Acknowledgements}

We thank Unni M. Roos and Hans Gunnar Espelien for excellent technical assistance with the experiments, and Rodmar Rivero for help with data collection and dissection of the plants.

\section{Author's contributions}

Research Professor AS contributed to the design of the study, analysis and interpretation of data, and writing of the manuscript. Professor Emer. $\mathrm{OMH}$ contributed to the design, the acquisition, and interpretation of the experiments, and did the major part of the writing of the manuscript. Both authors read and approved the final manuscript.

\section{Funding}

Funded by the European Union's Horizon 2020 research and innovation program (Grant Number 679303).

\section{Availability of data and materials}

The datasets analysed during the current study are available from the corresponding author on reasonable request.

Ethics approval and consent to participate

Not applicable.

\section{Consent for publication}

Not applicable.

\section{Competing interests}

The authors declare that they have no competing interests. 


\section{Author details}

${ }^{1} \mathrm{NIBIO}$, Norwegian Institute of Bioeconomy Research, 1431 Ås, Norway.

${ }^{2}$ Faculty of Environmental Sciences and Natural Resource Management,

Norwegian University of Life Sciences, 1432 Ås, Norway.

Received: 23 November 2020 Accepted: 11 January 2021

Published online: 22 January 2021

\section{References}

Darrow GM, Waldo GF. Responses of strawberry varieties and species to duration of the daily light period. US Department of Agriculture Tech Bull. 1934;453:1-31.

Guttridge CG. Fragaria x ananassa. In: Halevy AH, editor. Handbook of flowering, vol. III. Florida: CRC Press; 1985. p. 16-33.

Heide OM. Photoperiod and temperature interactions in growth and flowering of strawberry. Physiol Plant. 1977:40:21-6.

Heide OM, Stavang JA, Sønsteby A. Physiology and genetics of flowering in cultivated and wild strawberries_-a review. J Hortic Sci Biotech. 2013;88:1-18.

Ito H, Saito T. Studies on the flower formation in the strawberry plant. I. Effects of temperature on the flower formation. Tohoku J Agric Res. 1962;13:191-203.

Jonkers $\mathrm{H}$. On the flower formation, the dormancy and the early forcing of strawberries. Meded Landbouwhogesch Wageningen. 1965;65:1-71.

Kronenberg HG, Wassenaar LM, Van de Lindeloof CE. Effect of temperature on dormancy in strawberry. Sci Hortic. 1976;4:361-6.
Lang A. Physiology of flower initiation. In: Ruhland W, editor. Encyclopedia of plant physiology, vol. 15. Berlin: Springer; 1965. p. 1380-536.

Lieten P. Effects of chilling and night-break treatment on greenhouse production of 'Elsanta.' Acta Hortic. 1997;439:633-40.

Lieten P. Chilling requirements of strawberry cv. 'Sonata' and 'Figaro.' Acta Hortic. 2009;842:749-52.

Opstad N, Sønsteby A, Myrheim U, Heide OM. Seasonal timing of floral initiation in strawberry: effects of cultivar and geographic location. Sci Hortic. 2011;129:127-34.

Sønsteby A, Heide OM. Dormancy relations and flowering of the strawberry cultivars Korona and Elsanta as influenced by photoperiod and temperature. Sci Hortic. 2006;1 10:57-67.

Sønsteby A, Heide OM. Environmental regulation of dormancy and frost hardiness in Norwegian populations of wood strawberry (Fragaria vesca L.). Eur J Plant Sci Biotech. 2011;5(Special issue 1):42-8.

Sønsteby A, Solhaug KA, Heide OM. Functional growth analysis of 'Sonata' strawberry plants grown under controlled temperature and daylength conditions. Sci Hortic. 2016;211:26-33.

Takimoto A. Effect of sucrose on flower initiation of Pharbitis nil in aseptic culture. Plant Cell Physiol. 1960;1:241-6.

\section{Publisher's Note}

Springer Nature remains neutral with regard to jurisdictional claims in published maps and institutional affiliations.
Ready to submit your research? Choose BMC and benefit from:

- fast, convenient online submission

- thorough peer review by experienced researchers in your field

- rapid publication on acceptance

- support for research data, including large and complex data types

- gold Open Access which fosters wider collaboration and increased citations

- maximum visibility for your research: over 100M website views per year

At BMC, research is always in progress.

Learn more biomedcentral.com/submissions 